Jurnal Keperawatan Silampari

Volume 3, Nomor 2, Juni 2020

e-ISSN: 2581-1975

p-ISSN: 2597-7482

DOI: https://doi.org/10.31539/jks.v3i2.1119

\title{
TOLERANSI MINUM ENTERAL BAYI PREMATUR MENGGUNAKAN SPUIT 20 ML DAN SPUIT 50 ML
}

\author{
Elfira Awalia Rahmawati ${ }^{1}$, Yeni Rustina ${ }^{2}$, Defi Efendi ${ }^{3}$ \\ Akademi Keperawatan Pelni Jakarta ${ }^{1}$ \\ Universitas Indonesia ${ }^{2,3}$ \\ elfira.wijaya@gmail.com ${ }^{1}$
}

\begin{abstract}
ABSTRAK
Penelitian ini bertujuan untuk mengetahui perbandingan pemberian minum enteral dengan menggunakan spuit $20 \mathrm{ml}$ dan $50 \mathrm{ml}$ terhadap toleransi minum pada bayi prematur. Metode yang digunakan yaitu randomized controlled trial dengan desain crossover. Hasil penelitian ini menggambarkan terdapat perbedaan lama waktu yang signifikan pada kelompok intervensi pemberian minum menggunakan spuit $20 \mathrm{ml}$ dan spuit 50 pada hari pertama dan kedua ( $p$ value masing-masing adalah 0,$036 ; 0,033$ ), tidak ada perbedaan yang signifikan pada kelompok intervensi pemberian minum menggunakan spuit $20 \mathrm{ml}$ dan spuit $50 \mathrm{ml}$ pada hari ketiga ( $p$ value 0,984 ). Tidak terdapat perbedaan yang signifikan residu lambung pada hari pertama, kedua dan ketiga pada kedua kelompok intervensi. Kejadian muntah pada hari pertama, kedua dan ketiga tidak terdapat perbedaan yang signifikan pada kelompok intervensi pemberian minum menggunakan spuit $20 \mathrm{ml}$ dan spuit $50 \mathrm{ml}$ ( $p$ value masing-masing adalah 1,000). Simpulan, Pemberian minum enteral dengan menggunakan spuit $20 \mathrm{ml}$ dan spuit $50 \mathrm{ml}$ memiliki toleransi minum yang sama pada bayi prematur.
\end{abstract}

Kata kunci: Bayi prematur, Minum Enteral,Toleransi Minum

\section{ABSTRACT}

This study aims to determine the comparison of enteral drinking by using syringes of 20 $\mathrm{ml}$ and $50 \mathrm{ml}$ of drinking tolerance in preterm infants. The method used is a randomized controlled trial with a crossover design. The results of this study illustrate that there is a significant difference in the duration of the drinking intervention intervention group using $20 \mathrm{ml}$ syringes and 50 syringes on the first and second day ( $p$ value respectively 0.036; 0.033), there is no significant difference in the intervention group giving drinking using $20 \mathrm{ml}$ syringe and $50 \mathrm{ml}$ syringe on the third day (p value 0.984). There were no significant differences in gastric residue on the first, second and third day in the two intervention groups. The incidence of vomiting on the first, second and third day there was no significant difference in the intervention group of drinking using a $20 \mathrm{ml}$ syringe and $50 \mathrm{ml}$ syringe ( $p$ value each was 1,000). Conclusion, Provision of enteral drinking by using a $20 \mathrm{ml}$ syringe and $50 \mathrm{ml}$ syringe have the same drinking tolerance in premature babies.

Keywords: Premature Babies, Enteral Drinking, Tolerance to Drink 


\section{PENDAHULUAN}

Angka kematian bayi (AKB) merupakan indikator pertama dalam menentukan derajat kesehatan anak. Selain itu, angka kematian bayi juga merupakan cerminan dari status kesehatan masyarakat. Sebagian besar penyebab kematian bayi dan balita adalah masalah yang terjadi pada bayi yang baru lahir/neonatal (usia 0-28 hari). Prematuritas merupakan penyebab kematian terbesar kematian neonatus. Sebanyak 33\% penyebab kematian neonatal dini adalah prematuritas (Tarigan et al., 2017).

Bayi yang lahir dalam kondisi prematur memiliki kemampuan yang kurang dalam koordinasi menghisap dan menelan yang dibutuhkan untuk menyusu ke ibu atau minum melalui botol. Bayi prematur masih memiliki sistem gastrointestinal yang belum matur termasuk pengosongan lambung. Proses pengosongan lambung masih bersifat imatur meskipun pada bayi yang lahir cukup bulan, sehingga pada bayi prematur pengosongan lambung akan lebih lambat (Moore, Pickler, 2017). Patofisiologi dari intoleransi pemberian minum menunjukkan bahwa usus bayi prematur dan BBLR lebih pendek, fungsi absorbsi dan motilitas usus belum sempurna dibandingkan bayi aterm (Cresi et al., 2019).

Tanda objektif lain dari intoleransi minum yaitu meningkatnya residu lambung, emesis dan distensi abdomen (Wertheimer et al., 2019). Tanda-tanda tersebut juga merupakan prekursor terjadinya nekrotizing enterocolitis (NEC) yang menjadi salah satu penyebab mortalitas dan morbiditas pada bayi prematur (Abiramalatha et al., 2018). Bayi prematur yang mengalami NEC dan atau intoleransi pemberian minum dapat menimbulkan masalah seperti perkembangan saluran pencernaan terhambat dan kekurangan kalori yang dapat menyebabkan masalah dalam pemenuhan kebutuhan nutrisi.

Intervensi pemberian minum enteral pada bayi prematur sangat penting untuk menstimulasi sistem gastrointestinal dan untuk memenuhi kebutuhan nutrisi pada bayi tersebut (Moore, Pickler, 2017). Pemberian nutrisi secara tepat diperlukan untuk proses maturasi dan perkembangan saluran pencernaan, penyerapan, dan fungsi motorik (Padila, Agustien, 2019). Nutrisi dapat diberikan menggunakan orogastric tube (OGT) atau nasogastric tube (NGT) dengan teknik gravitasi. Pemberian minum enteral secara gravitasi dapat mencegah peningkatan tekanan dalam perut bayi sehingga menurunkan risiko regurgitasi. Spuit yang digunakan dalam pemberian makan merupakan salah satu yang berpengaruh terhadap kecepatan dan volume yang diberikan.

Berdasarkan hasil pengamatan selama praktik di ruang perinatologi, didapatkan bahwa pemberian minum enteral pada bayi prematur secara gravitasi sebagian besar menggunakan spuit $50 \mathrm{ml}$. Ukuran spuit yang besar akan menghasilkan kecepatan yang tinggi yang mempunyai dampak pada peningkatan tekanan intragastrik dan kejadian muntah. Ukuran spuit yang lebih kecil diperlukan untuk menurunkan tekanan intragastrik sehingga kejadian muntah dapat dihindari.

Selain itu, sampai saat ini belum ada panduan mengenai ukuran spuit yang digunakan dalam pemberian minum enteral pada bayi yang mengalami intoleransi minum. Penelitian ini bertujuan untuk mengetahui perbandingan pemberian minum enteral dengan menggunakan spuit $20 \mathrm{ml}$ dan $50 \mathrm{ml}$ terhadap toleransi minum pada bayi prematur. 


\section{METODE PENELITIAN}

\section{Desain penelitian}

Desain yang digunakan dalam penelitian ini adalah menggunakan pendekatan uji klinis acak terkontrol (randomized controlled trial) dengan desain crossover (desain menyilang). Data dengan distribusi normal menggunakan uji $t$ dependen sedangkan data dengan distribusi tidak normal menggunakan uji Wilcoxon. Perbedaan kejadian muntah pada kelompok intervensi pemberian minum menggunakan spuit $20 \mathrm{ml}$ dan spuit $50 \mathrm{ml}$ menggunakan uji Mc Nemar. Hubungan karakteristik responden terhadap lama waktu pemberian minum dan residu lambung dianalisis menggunakan uji korelasi Pearson untuk sebaran data normal dan uji Spearman untuk sebaran data tidak normal. Hubungan karakteristik terhadap kejadian muntah dianalisis menggunakan uji korelasi Lamda.

\section{Intervention group}

Penelitian ini menerapkan dua intervensi yaitu intervensi pemberian nutrisi enteral dengan menggunakan spuit $20 \mathrm{ml}$ dan pemberian nutrisi enteral dengan menggunakan spuit $50 \mathrm{ml}$ pada bayi prematur. Semua sampel dalam penelitian ini akan memperoleh kedua intervensi tersebut pada waktu yang berbeda dan urutan intervensi dilakukan dengan proses pengacakan (randomisasi). Randomisasi yang digunakan yaitu metode acak sederhana (simple random sampling) dengan melempar mata uang. Intervensi pemberian nutrisi enteral dengan menggunakan spuit $20 \mathrm{ml}$ dan $50 \mathrm{ml}$ dilakukan selama 3 hari berturut-turut.

Jumlah sampel minimal yang diperlukan yaitu 25 bayi. Kriteria inklusi sampel yang digunakan yaitu bayi dengan usia gestasi kurang dari 37 minggu, bayi prematur yang mendapatkan nutrisi enteral melalui orogastric tube (OGT) dengan metode gravitasi, bayi prematur yang mendapatkan nutrisi enteral lebih dari $150 \mathrm{ml} / \mathrm{kgbb} / \mathrm{hari}$. Kriteria eksklusi: Bayi dengan riwayat NEC, bayi dengan gangguan kongenital pada sistem pencernaan. Ukuran OGT yang digunakan adalah nomor 6 dengan panjang selang $100 \mathrm{~cm}$.

\section{Ethical Consideration}

Penelitian ini dilakukan setelah mendapatkan persetujuan dari Komite Etik Penelitian Fakultas Ilmu Keperawatan Universitas Indonesia No.217/UN2. F12.D/ HKP.02.04/2018.

\section{HASIL PENELITIAN Hasil Analisis Univariat}

Tabel. 1

Karakteristik Responden berdasarkan Usia Gestasi, Usia Kronologis, Berat Badan dan Jenis Kelamin Bayi Prematur Bulan Maret-April $2018(\mathrm{n}=25)$

\begin{tabular}{ccccc}
\hline Variabel & Median & Mean \pm SD & \multicolumn{2}{c}{$95 \%$ CI } \\
\cline { 4 - 5 }$($ min-maks) & & $32,76 \pm 2.22$ & 31,84 & 33,68 \\
\hline Usia Gestasi & $33,00(27-36)$ & $11 \pm 7,159$ & 8,04 & 13,96 \\
Usia Kronologis & $8(3-26)$ & & & 1872,50 \\
Berat badan hari & 1735,00 & $1738,32 \pm 325,054$ & 1604,14 & 180 \\
pertama & $(1270-2645)$ & &
\end{tabular}




\begin{tabular}{ccccc} 
Berat badan hari kedua & 1735,00 & $1753,72 \pm 331,649$ & 1616,82 & 1890,62 \\
& $(1270-2645)$ & & & \\
Berat badan hari ketiga & 1743,00 & $1806,32 \pm 434,826$ & 1626,83 & 1985,81 \\
& $(1295-2675)$ & & & \\
\hline Variabel & Frekuensi & Persentase (\%) & & \\
\hline Jenis kelamin & & & & \\
Laki-laki & 11 & 44 & \\
Perempuan & 14 & 56 & \\
\hline
\end{tabular}

Tabel 1 menunjukkan bahwa dari 25 responden pada intervensi pemberian minum menggunakan spuit $20 \mathrm{ml}$ dan $50 \mathrm{ml}$, nilai tengah usia gestasi adalah 32,76. Rerata usia kronologis bayi prematur adalah 11 hari. Rerata berat badan bayi prematur hari pertama, kedua dan ketiga adalah 1738,32 gram; 1753,72 gram dan 1806,32 gram. Jenis kelamin paling banyak adalah responden laki-laki sebanyak 14 bayi $(56,0 \%)$ dan perempuan sebanyak 11 bayi $(44,0 \%)$.

\section{Distribusi Frekuensi Variabel Lama Waktu Pemberian, Residu Lambung, Lingkar Perut dan Volume Susu Rerata Lama Waktu Pemberian Minum}

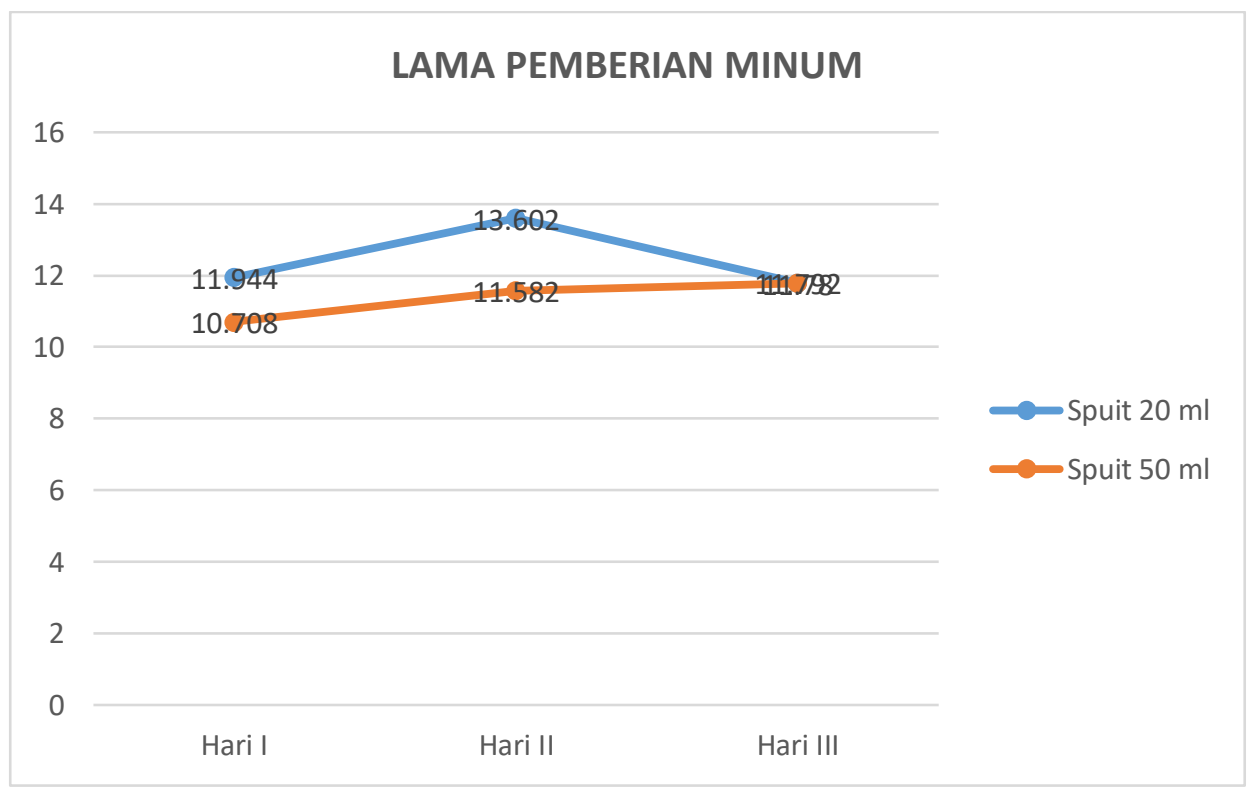

Grafik. 1

Kurva Rerata Lama Waktu Pemberian Minum Bayi Prematur Bulan Maret-April $2018(\mathrm{n}=25)$

Grafik 1 menununjukkan bahwa rata-rata lama waktu pemberian minum menggunakan spuit $20 \mathrm{ml}$ pada hari pertama dan kedua lebih lama dibandingkan dengan lama waktu pemberian minum menggunakan spuit $50 \mathrm{ml}$. Pada hari ketiga menunjukkan rerata lama waktu pemberian minum yang sama antara menggunakan spuit $20 \mathrm{ml}$ dan spuit $50 \mathrm{ml}$. 


\section{Rerata Residu Lambung pada Bayi Prematur}

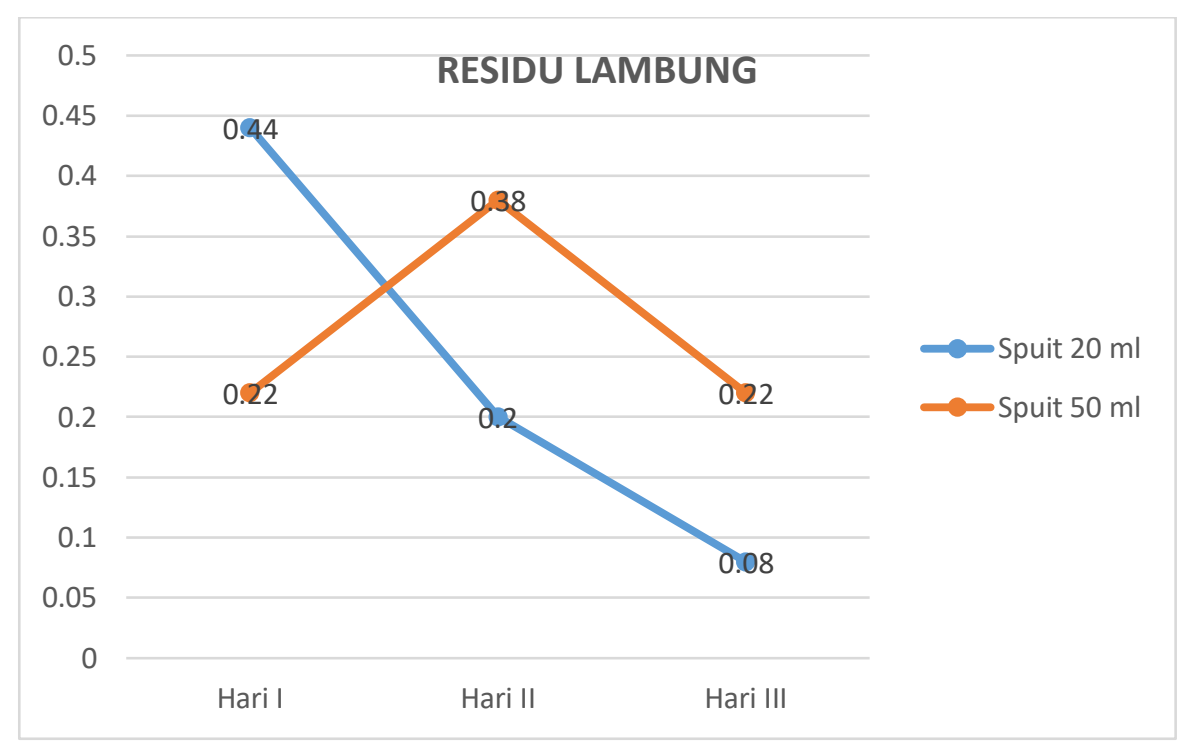

Grafik. 2

Kurva Rerata Residu Lambung Bayi prematur

Bulan Maret-April $2018(\mathrm{n}=25)$

Grafik 2 menunjukkan rerata residu lambung kelompok pemberian minum spuit $20 \mathrm{ml}$ pada hari pertama, kedua dan ketiga mengalami penurunan jumlah residu lambung. Sedangkan kelompok intervensi residu lambung menggunakan spuit $50 \mathrm{ml}$ rerata residu lambung hari pertama mengalami peningkatan jumlah residu lambung pada hari kedua dan kembali menurun pada hari ketiga dengan jumlah residu lambung yang sama dengan hari pertama.

\section{Kejadian Muntah pada Bayi Prematur}

Tabel. 2

Kejadian Muntah Bayi Prematur Bulan Maret-April 2018

$(\mathrm{n}=25)$

\begin{tabular}{|c|c|c|c|c|c|c|c|}
\hline \multirow{2}{*}{ Variabel } & \multirow{2}{*}{ Kelompok } & \multicolumn{2}{|c|}{$\begin{array}{l}\text { Kejadian muntah hari } \\
\text { pertama }\end{array}$} & \multicolumn{2}{|c|}{$\begin{array}{l}\text { Kejadian muntah } \\
\text { hari kedua }\end{array}$} & \multicolumn{2}{|c|}{$\begin{array}{l}\text { Kejadian muntah } \\
\text { hari ketiga }\end{array}$} \\
\hline & & Muntah & $\begin{array}{c}\text { Tidak } \\
\text { muntah }\end{array}$ & Muntah & $\begin{array}{c}\text { Tidak } \\
\text { muntah }\end{array}$ & Muntah & $\begin{array}{c}\text { Tidak } \\
\text { muntah }\end{array}$ \\
\hline \multirow{2}{*}{$\begin{array}{l}\text { Kejadian } \\
\text { muntah }\end{array}$} & $\begin{array}{c}\text { Spuit } 20 \\
\mathrm{ml}\end{array}$ & 1 & 24 & 1 & 24 & 2 & 23 \\
\hline & $\begin{array}{l}\text { Spuit } 50 \\
\mathrm{ml}\end{array}$ & 1 & 24 & 2 & 23 & 1 & 24 \\
\hline
\end{tabular}

Tabel 2 menunjukkan bahwa pada kelompok intervensi pemberian minum menggunakan spuit $20 \mathrm{ml}$ dan spuit $50 \mathrm{ml}$ menunjukan jumlah yang sebanding terhadap kejadian muntah pada hari pertama, hari kedua dan hari ketiga. 


\section{Rerata Volume Susu Bayi Prematur}

Tabel. 3

Rerata Volume Susu Bayi Prematur

Bulan Maret-April $2018(\mathrm{n}=25)$

\begin{tabular}{ccccc}
\hline Variabel & Median & Mean \pm SD & \multicolumn{2}{c}{$95 \%$ CI } \\
\cline { 4 - 5 }$\left(\begin{array}{c}\text { min-maks }) \\
\text { Volume Susu hari }\end{array}\right.$ & 25,00 & $27,76 \pm 7,758$ & 24,56 & 30,96 \\
pertama & $(20-45)$ & & & \\
Volume Susu hari kedua & 30,00 & $29,72 \pm 7,871$ & 26,47 & 32,97 \\
& $(20-48)$ & & & \\
Volume Susu hari ketiga & 30,00 & $30,88 \pm 7,429$ & 27,81 & 33,95 \\
\hline
\end{tabular}

Tabel 3 menunjukkan rerata volume susu bayi prematur hari pertama, kedua dan ketiga responden pada kelompok intervensi pemberian minum menggunakan spuit 20 $\mathrm{ml}$ dan spuit $50 \mathrm{ml}$ adalah 27,76 ml; 29,72 $\mathrm{ml}$ dan $30,88 \mathrm{ml}$.

\section{Hasil Analisis Bivariat \\ Perbedaan Rerata Lama Waktu Pemberian Minum dan Residu Lambung}

Tabel. 4

Perbedaan Rerata Lama Waktu Pemberian Minum dan Residu Lambung Berdasarkan Kelompok Intervensi Bulan Maret-April 2018 ( $\mathrm{n}=25)$

\begin{tabular}{|c|c|c|c|}
\hline Variabel & Kelompok & Mean & $P$ value \\
\hline \multirow{2}{*}{$\begin{array}{l}\text { Lama pemberian minum hari } \\
\text { pertama }\end{array}$} & Spuit $20 \mathrm{ml}$ & 11,944 & \multirow{2}{*}{$0,036^{*}$} \\
\hline & Spuit $50 \mathrm{ml}$ & 10,708 & \\
\hline \multirow{2}{*}{$\begin{array}{l}\text { Lama pemberian minum hari } \\
\text { kedua }\end{array}$} & Spuit $20 \mathrm{ml}$ & 13,602 & \multirow{2}{*}{$0,033^{*}$} \\
\hline & Spuit $50 \mathrm{ml}$ & 11,582 & \\
\hline \multirow{2}{*}{$\begin{array}{l}\text { Lama pemberian minum hari } \\
\text { ketiga }\end{array}$} & Spuit $20 \mathrm{ml}$ & 11,792 & \multirow{2}{*}{0,984} \\
\hline & Spuit $50 \mathrm{ml}$ & 11,780 & \\
\hline \multirow{2}{*}{ Residu lambung hari pertama } & Spuit $20 \mathrm{ml}$ & 0,440 & \multirow{2}{*}{0,180} \\
\hline & Spuit $50 \mathrm{ml}$ & 0,220 & \\
\hline \multirow{2}{*}{$\begin{array}{l}\text { Residu lambung } \\
\text { hari kedua }\end{array}$} & Spuit $20 \mathrm{ml}$ & 0,20 & \multirow{2}{*}{0,109} \\
\hline & Spuit $50 \mathrm{ml}$ & 0,380 & \\
\hline \multirow{2}{*}{$\begin{array}{l}\text { Residu lambung } \\
\text { hari ketiga }\end{array}$} & Spuit $20 \mathrm{ml}$ & 0,080 & \multirow{2}{*}{0,655} \\
\hline & Spuit $50 \mathrm{ml}$ & 0,220 & \\
\hline
\end{tabular}

* Signifikan $\mathrm{p}<0,05$

Tabel 4 menunjukkan terdapat perbedaan yang signifikan pada kelompok intervensi pemberian minum menggunakan spuit $20 \mathrm{ml}$ dan spuit 50 pada hari pertama dan kedua ( $p$ value masing-masing adalah 0,$036 ; 0,033$ ) dan tidak ada perbedaan yang signifikan pada kelompok intervensi pemberian minum menggunakan spuit $20 \mathrm{ml}$ dan spuit $50 \mathrm{ml}$ pada hari ketiga ( $p$ value 0,984). Residu lambung pada hari pertama, kedua dan ketiga tidak ada perbedaan yang signifikan pada kelompok intervensi pemberian 
minum menggunakan spuit $20 \mathrm{ml}$ dan spuit $50 \mathrm{ml}$ ( $p$ value masing-masing adalah 0,180 ; $0,109 ; 0,655)$.

\section{Perbedaan Kejadian Muntah}

Tabel. 5

Perbedaan Kejadian Muntah Berdasarkan Kelompok Intervensi Bulan Maret-April $2018(\mathrm{n}=25)$

\begin{tabular}{|c|c|c|c|c|c|c|c|c|c|c|}
\hline & & \multicolumn{2}{|c|}{$\begin{array}{l}\text { Kejadian Muntah } \\
\text { Hari Pertama }\end{array}$} & \multirow{2}{*}{$\begin{array}{c}P \\
\text { value }\end{array}$} & \multicolumn{2}{|c|}{$\begin{array}{l}\text { Kejadian Muntah } \\
\text { Hari Kedua }\end{array}$} & \multirow{2}{*}{$\begin{array}{c}P \\
\text { value }\end{array}$} & \multicolumn{2}{|c|}{$\begin{array}{l}\text { Kejadian Muntah } \\
\text { Hari Ketiga }\end{array}$} & \multirow{2}{*}{$\begin{array}{c}P \\
\text { valu } \\
e\end{array}$} \\
\hline & & Muntah & $\begin{array}{l}\text { Tidak } \\
\text { Muntah }\end{array}$ & & Muntah & $\begin{array}{l}\text { Tidak } \\
\text { Muntah }\end{array}$ & & Muntah & $\begin{array}{l}\text { Tidak } \\
\text { Muntah }\end{array}$ & \\
\hline \multirow{2}{*}{$\begin{array}{l}\text { Kelo } \\
\text { mpok }\end{array}$} & $\begin{array}{l}\text { Spuit } \\
20 \mathrm{ml}\end{array}$ & 1 & 24 & \multirow{2}{*}{1,000} & 1 & 24 & \multirow{2}{*}{1,000} & 2 & 23 & \multirow{2}{*}{$\begin{array}{l}1,0 \\
00\end{array}$} \\
\hline & $\begin{array}{l}\text { Spuit } \\
50 \mathrm{ml}\end{array}$ & 1 & 24 & & 2 & 23 & & 1 & 24 & \\
\hline & Total & 2 & 48 & & 3 & 47 & & 3 & 47 & \\
\hline
\end{tabular}

Tabel 5 menunjukkan bahwa kejadian muntah pada hari pertama, kedua dan ketiga tidak terdapat perbedaan yang signifikan pada kelompok intervensi pemberian minum menggunakan spuit $20 \mathrm{ml}$ dan spuit $50 \mathrm{ml}$ ( $p$ value masing-masing adalah $1,000)$.

\section{Hubungan Karakteristik Responden Terhadap Lama Waktu Pemberian Minum, Residu Lambung dan Kejadian Muntah}

Tabel. 6

Hubungan Karakteristik Responden Terhadap Lama Waktu Pemberian Minum, Residu Lambung dan Muntah Berdasarkan Kelompok Intervensi Bulan Maret-April 2018 ( $\mathrm{n}=25)$

\begin{tabular}{ccccccc}
\hline \multirow{2}{*}{ Parameter } & \multicolumn{9}{c}{ Kelompok Intervensi } \\
\cline { 2 - 7 } & \multicolumn{2}{c}{$\begin{array}{c}\text { Lama Waktu } \\
\text { Pemberian Minum }\end{array}$} & Residu Lambung & \multicolumn{2}{c}{ Muntah } \\
\cline { 2 - 7 } & $r$ & $p$ & $r$ & $P$ & $r$ & $P$ \\
\hline Usia Gestasi & $-0,067$ & 0,644 & 0,293 & $0,039^{*}$ & 0,083 & $0,040^{*}$ \\
Usia Kronologis & 0,633 & 0,062 & $-0,258$ & 0,213 & 0,307 & 1,00 \\
Berat Badan & 0,280 & 0,174 & 0,109 & 0,603 & 0,740 & 0,612 \\
Volume Susu & 0,321 & $0,023^{*}$ & $-0,120$ & 0,406 & 0,149 & 1,00 \\
Jenis Kelamin & 0,035 & 0,561 & 0,307 & 0,637 & 1,000 & 0,861 \\
\hline
\end{tabular}

* Signifikan $\mathrm{p}<0,05$

Tabel 6 menunjukkan hasil bahwa usia gestasi mempunyai hubungan yang bermakna terhadap residu lambung dan kejadian muntah $(p<0,05)$, namun mempunyai hubungan yang tidak bermakna terhadap lama pemberian waktu minum $(p>0,05)$. Usia kronologis, berat badan dan jenis kelamin tidak mempunyai hubungan yang bermakna terhadap lama pemberian minum, residu lambung dan kejadian muntah $(p>0,05)$. Volume susu mempunyai hubungan yang bermakna terhadap lama waktu pemberian minum $(\mathrm{p}<0,05)$, namun mempunyai hubungan yang tidak bermakna dengan residu lambung dan muntah. 


\section{PEMBAHASAN}

\section{Karakteristik Bayi}

\section{Usia Gestasi dan Usia Kronologis}

Karakteristik bayi pada penelitian ini meliputi usia gestasi, usia kronologis, jenis kelamin dan berat badan bayi. Hasil penelitian menunjukkan rerata usia gestasi adalah 32,76 minggu. Rerata usia gestasi pada penelitian ini termasuk dalam bayi prematur. Pemberian nutrisi pada bayi berat lahir rendah dan bayi prematur mempunyai tantangan yang unik karena belum maturnya saluran pencernaan. Bayi berat lahir rendah dan bayi prematur mendapatkan nutrisi enteral dengan volume yang sesuai dengan nutrisi optimal yang memenuhi kriteria pertumbuhan. Hambatan pemberian makan dengan volume lanjutan sering berhubungan dengan kejadian intoleransi minum pada bayi prematur. Perkembangan ketrampilan oral motor pada bayi prematur usia gestasi kurang dari 34 minggu belum dapat mengkoordinasikan secara simultan reflek menghisap, menelan dan bernapas sehingga pemberian nutrisi melalui parenteral maupun enteral (Song et al., 2019). Nutrisi enteral lebih baik dibandingkan nutrisi parenteral. Pemberian nutrisi secara enteral mampu merangsang pematangan gastrointestinal dan mencegah atrofi usus. Pematangan anatomi saluran pencernaan sebagian besar lengkap pada usia gestasi 20 minggu, tetapi pematangan fungsional termasuk motilitas usus, sekresi asam lambung sfingter gastroesofagus, aktivitas enzim dan asam empedu lengkap sampai usia gestasi matur.

Rerata usia kronologis pada penelitian ini adalah 11 hari. Usia kronologis tidak berhubungan dengan intoleransi minum, hal ini disebabkan karena pemberian nutrisi awal sangat penting diberikan untuk meningkatkan pertumbuhan optimal, mengurangi risiko infeksi dan menurunkan morbiditas (Kumar et al., 2017). Nutrisi awal ditoleransi baik dan efektif meningkatkan pertumbuhan dan menstimulasi maturasi saluran cerna pada bayi prematur (Nangia et al., 2018; Salas et al., 2020).

\section{Berat Badan}

Rerata berat badan badan responden pada penelitian ini adalah renatng 1700-1800 gram. Bayi termasuk dalam dalam klasifikasi bayi berat lahir rendah. Bayi berat lahir rendah (BBLR) didefinisikan oleh Organisasi Kesehatan Dunia (WHO) sebagai berat badan saat lahir kurang dari $2,5 \mathrm{~kg}$. Nutrisi yang adekuat sangat penting untuk pertumbuhan optimal bayi berat lahir rendah (Padila et al., 2018). Nutrisi enteral lebih diutamakan dibandingkan nutrisi parenteral karena dapat menghindari komplikasi yang terkait kateterisasi vascular, sepsis, dan efek merugikan. Nutrisi parenteral tetap penting diberikan sebagai tambahan nutrisi enteral. Tujuan pemberian nutrisi pada BBLR adalah untuk mencapai asupan enteral penuh dalam waktu singkat namun tetap mempertahankan pertumbuhan dan nutrisi optimal dan menghindari konsekuensi buruk dari kemajuan makan yang cepat (Kumar et al., 2017).

\section{Jenis Kelamin}

Responden dalam penelitian ini mayoritas berjenis kelamin laki-laki. Menurut pemikiran peneliti, jumlah responden laki-laki lebih banyak pada penelitian ini dikarenakan faktor kebetulan saja karena pada saat penelitian ini dilakukan kelahiran bayi laki-laki lebih banyak dari pada bayi perempuan. Jenis kelamin tidak mempunyai hubungan yang bermakna terhadap lama waktu pemberian, residu lambung dan kejadian muntah $(\mathrm{p}>0,05)$. Jenis kelamin, usia ibu, pola makan tidak berhubungan dengan kejadian intoleransi minum (Haghshenas et al., 2020). 


\section{Pemberian Minum Menggunakan Spuit 20 ml dan Spuit 50 ml Secara Gravitasi Terhadap Lama Waktu Pemberian, Residu Lambung dan Kejadian Muntah. Lama pemberian waktu minum}

Hasil penelitian menunjukkan terdapat perbedaan lama waktu pemberian minum yang signifikan pada kelompok intervensi pemberian minum menggunakan spuit $20 \mathrm{ml}$ dan spuit $50 \mathrm{ml}$ pada hari pertama dan kedua, namun tidak terdapat perbedaan pada hari ketiga. Rerata lama waktu pemberian minum pada spuit $50 \mathrm{ml}$ lebih cepat dibandingkan pemberian minum menggunakan spuit $20 \mathrm{ml}$. Menurut Sojasi et al., (2018) mengatakan bahwa pemberian minum menggunakan metode gravitasi akan memerlukan waktu 10 sampai 15 menit untuk sampai ke abdomen bayi. Pemberian minum enteral melalui gravitasi menggunakan selang berukuran 6 yang terhubung dengan spuit $20 \mathrm{ml}$ (Joshi et al., 2017).

Kecepatan aliran susu dapat dipengaruhi oleh adanya sumbatan pada selang OGT. Sumbatan terjadi apabila pembilasan selang OGT tidak dilakukan. Pembilasan selang dengan menggunakan air dapat mencegah sumbatan. Air merupakan solusi pembilasan paling efektif dalam mempertahankan kepatenan selang OGT. Beberapa kondisi medis pasien perlu dipertimbangkan dalam memutuskan volume dan frekuensi air yang digunakan. Aspirasi lambung juga dapat membentuk sumbatan jika pembilasan selang OGT tidak dilakukan. Sumbatan yang terjadi pada selang OGT akan mempengaruhi lamanya waktu pengosongan susu pada spuit (Best, 2019).

\section{Residu Lambung}

Residu lambung pada hari pertama, kedua dan ketiga menunjukkan tidak ada perbedaan yang signifikan pada kelompok intervensi pemberian minum menggunakan spuit $20 \mathrm{ml}$ dan spuit $50 \mathrm{ml}$. Rerata residu pada spuit $50 \mathrm{ml}$ lebih tinggi dibandingkan pemberian minum menggunakan spuit $20 \mathrm{ml}$ pada hari kedua dan ketiga.

Pengosongan lambung dapat dipengaruhi oleh beberapa faktor, yaitu usia bayi, jenis formula, serta posisi pemberian nutrisi. Pada bayi prematur dengan intoleransi minum, keterlambatan nutrisi enteral dapat menyebabkan masalah seperti keterlambatan perkembangan saluran intestinal dan kurangnya kebutuhan kalori. Pencegahan terhadap residu lambung yang terus meningkat merupakan tantangan besar dalam perawatan bayi premature (Ameri et al., 2018).

Hubungan karakteristik usia gestasi dengan residu lambung menunjukkan hasil bahwa usia gestasi mempunyai hubungan yang bermakna terhadap residu lambung. Usia kehamilan yang rendah, berat lahir rendah, keterlambatan pemberian makan berhubungan dengan perkembangan intoleransi pada bayi prematur. Usia gestasi sangat mempengaruhi kematangan suatu organ tubuh pada bayi prematur. Sistem pencernaan merupakan sistem organ yang melaksanakan fungsi digesti dan absorbsi, keseimbangan cairan dan elektrolit, imunitas, endokrin, dan persyarafan untuk memenuhui kebutuhan energi tubuh. Fungsi mekanis sistem pencernaan bayi prematur yang mengalami immaturitas adalah pengosongan lambung. Pengosongan lambung bayi prematur terjadi lebih lambat dibandingkan dengan bayi cukup bulan (Riskin et al., 2017).

Jenis susu yang terbaik untuk bayi adalah air susu ibu (ASI). Air susu ibu memiliki manfaat untuk sistem pencernaan khususnya berkaitan dengan rendahnya insiden NEC dan diare selama periode awal kehidupan. Kandungan ASI berubah sesuai dengan kondisi dan kebutuhan bayi sehingga lebih mudah. Bayi yang mendapatkan ASI eksklusif sangat jarang mengalami malabsorbsi lactase dan sindrom intoleransi. Hal ini yang membuat ASI lebih aman dibandingkan susu formula (Martin et al., 2016). 
Bayi yang mendapatkan ASI dapat menyerap lemak lebih banyak dibandingkan bayi yang mendapatkan susu formula karena kandungan lipase dalam ASI yang tidak ada dalam susu sapi. Kandungan protein yang tinggi di dalam susu formula dapat mempengaruhi keterlambatan waktu pengosongan lambung (Martin et al., 2016; Nangia et al., 2018; Salas et al., 2020). Selain itu, kandungan laktosa dalam susu matang (setelah 21 hari postpartum) cukup konstan. Konsentrasi laktosa yang stabil penting dalam menjaga tekanan osmotik konstan dalam ASI, membantu penyerapan mineral dan kalsium.

Posisi bayi pada saat pemberian minum juga mempengaruhi pengosongan lambung. Posisi pronasi menghasilkan residu lambung lebih rendah dibandingkan posisi supine pada menit ke 30, 60, 90, 120 dan 150 dengan volume minum 50-100 $\mathrm{ml} / \mathrm{kgbb} / \mathrm{hari}$. Posisi pronasi direkomendasikan untuk menurunkan residu lambung setelah pemberian minum dibandingkan posisi lateral kiri (Ameri et al., 2018; Khatony et al., 2019).

\section{Kejadian Muntah}

Hasil penelitian menunjukkan bahwa perbedaan kejadian muntah pada hari pertama, kedua dan ketiga secara statistik menggunakan uji Mc Nemar tidak terdapat perbedaan yang signifikan pada kelompok intervensi pemberian minum menggunakan spuit $20 \mathrm{ml}$ dan spuit $50 \mathrm{ml}$. Usia gestasi mempunyai hubungan yang bermakna dengan kejadian muntah. Gastroesofagus reflux (GER) atau muntah sangat umum terjadi pada bayi prematur akibat mekanisme fisiologis dan patofisiologis. Bayi prematur yang lahir sebelum 34 minggu, $22 \%$ mengalami muntah.

Ukuran spuit yang besar akan menghasilkan kecepatan yang tinggi yang mempunyai dampak pada peningkatan tekanan intragastrik dan kejadian muntah. Ukuran spuit yang lebih kecil diperlukan untuk menurunkan tekanan intragastrik sehingga kejadian muntah dapat dihindari (Una, 2019).

\section{Volume Susu}

Hasil penelitian menunjukkan volume susu mempunyai hubungan yang bermakna terhadap lama waktu pemberian minum $(\mathrm{p}<0,05)$. Pemberian minum melalui gravitasi dengan volume minum yang lebih kecil membutuhkan waktu tidak lebih cepat dari $2 \mathrm{ml}$ per menit, sedangkan pemberian minum dengan volume yang lebih besar membutuhkan waktu sekitar 15 menit (National Patient Care Teams, 2017). Volume susu yang diberikan menggunakan spuit secara gravitasi mengalir secara perlahan sehingga membutuhkan waktu lebih dari 20 menit (Nursing Clinical Effectiveness Committee, 2017).

\section{SIMPULAN}

Terdapat perbedaan lama waktu yang signifikan pada kelompok intervensi pemberian minum menggunakan spuit $20 \mathrm{ml}$ dan spuit $50 \mathrm{ml}$ pada hari pertama dan kedua, tidak ada perbedaan yang signifikan pada kelompok intervensi pemberian minum menggunakan spuit $20 \mathrm{ml}$ dan spuit $50 \mathrm{ml}$ pada hari ketiga. Tidak terdapat perbedaan yang signifikan residu lambung pada hari pertama, kedua dan ketiga pada kedua kelompok intervensi. Kejadian muntah pada hari pertama, kedua dan ketiga tidak terdapat perbedaan yang signifikan pada kelompok intervensi pemberian minum menggunakan spuit $20 \mathrm{ml}$ dan spuit $50 \mathrm{ml}$. 


\section{SARAN}

Intervensi pemberian minum menggunakan spuit $20 \mathrm{ml}$ dapat digunakan untuk menurunkan residu lambung pada bayi prematur yang diberikan nutrisi enteral gravitasi. Intervensi pemberian minum menggunakan spuit $20 \mathrm{ml}$ dapat digunakan untuk pemberian nutrisi enteral gravitasi dikarenakan tekanan yang diberikan lebih kecil sehingga waktu pengosongan spuit lebih lama. Rekomendasi penelitian selanjutnya perlu dilakukan penelitian dengan menggunakan kelompok kontrol dan menganilisis jenis susu yang diberikan.

\section{DAFTAR PUSTAKA}

Abiramalatha, T., Thanigainathan, S., \& Ninan, B. (2018). Routine Monitoring of Gastric Residual for Prevention of Necrotising Enterocolitis in Preterm Infants. Cochrane Database of Systematic Reviews, 1, 1-10. https://doi.org/https://doi.org/10.1002/14651858.CD012937

Ameri, G., Rostami, S., Baniasadi, H., Aboli, B., \& Ghorbani, F. (2018). The Effect of Prone Position on Gastric Residuals in Preterm Infants. Journal of Pharmaceutical Research International, 22(2), 1-6. https://doi.org/10.9734/jpri/2018/40433

Best, C. (2019). Selection and Management of Commonly Used Enteral Feeding Tubes. Nursing Times, 115(3), 43-47

Committee, N. C. E. (2017). Enteral Feeding And Medication Administration. The Royal Children's Hospital

Cresi, F., Manggiora, E., Borgione, S. M., Spada, E., Coscia, A., Betino, E., Meneghin, F., Corvaglia, L. T., Ventura, M. L., Lista, G., \& Group, E. S. R. (2019). Enteral Nutrition Tolerance and REspiratory Support (ENTARES) Study in Preterm Infants: Study Protocol for a Randomized Controlled Trial. BMC, 20(69). https://doi.org/10.1186/s13063-018-3119-0

Haghshenas, M. M., Jafarian, A. S. R., Dalili, H., Khafri, S., \& Hamed, F. (2020). The Effect of Abdominal Massage on the Feeding Tolerance of Neonates with Very Low Birth Weight. Iranian Journal of Pediatrics, 30(2), 1-5. https://doi.org/10.5812/ijp.95074

Joshi, R., Van, P. C., Sanders, A., Weda, H., Bikker, J. W., Feijs, L., \& Andriessen, P. (2017). A Strategy to Reduce Critical Cardiorespiratory Alarms due to Intermittent Enteral Feeding of Preterm Neonates in Intensive Care. Interactive Journal of Medical Research, 6(2), e20. https://doi.org/10.2196/ijmr.7756

Khatony, A., Abdi, A., Karimi, B., Aghaei, A., \& Brojeni, H. S. (2019). The Effects of Position on Gastric Residual Volume of Premature Infants in NICU. Italian Journal of Pediatrics, 45(1). https://doi.org/10.1186/s13052-018-0591-9

Kumar, R. K., Singhal, A., Vaidya, U., Banerjee, S., Anwar, F., \& Rao, S. (2017). Optimizing Nutrition In Preterm Low Birth Weight Infants-Consensus Summary. $\begin{array}{llll}\text { Frontiers in } & \text { Nutrition, }\end{array}$ https://doi.org/https://doi.org/10.3389/fnut.2017.00020

Martin, C. R., Ling, P. R., \& Blackburn, G. L. (2016). Review of Infant Feeding: Key Features of Breast Milk and Infant Formula. In Nutrients, 8(5), 279-289. https://doi.org/10.3390/nu8050279

Moore, T. A., \& Pickler, R. H. (2017). Feeding Intolerance, Inflammation, and Neurobehaviors in Preterm Infants. $J$ Neonatal Nurse, 23(3), 134-141. https://doi.org/http://doi:10.1016/j.jnn.2016.09.009 
Nangia, S., Bishnoi, A., Goel, A., Mandal, P., Tiwari, S., \& Saili, A. (2018). Early Total Enteral Feeding in Stable Very Low Birth Weight Infants: A Before and After $\begin{array}{lllll}\text { Study. } & J & \text { Trop } & \text { 24-30. }\end{array}$ https://doi.org/https://doi.org/10.1159/000496015

Padila, P., \& Agustien, I. (2019). Suhu Tubuh Bayi Prematur di Inkubator Dinding Tunggal dengan Inkubator Dinding Tunggal Disertai Sungkup. Jurnal Keperawatan Silampari, 2(2), 113-122. https://doi.org/10.31539/jks.v2i2.651

Padila, P., Amin, M., \& Rizki, R. (2018). Pengalaman Ibu dalam Merawat Bayi Preterm yang Pernah dirawat di Ruang Neonatus Intensive Care Unit Kota Bengkulu. Jurnal Keperawatan Silampari, 1(2), 1-16. https://doi.org/10.31539/jks.v1i2.82

Riskin, A., Cohen, K., Kugelman, A., Toropine, A., Said, W., \& Bader, D. (2017). The Impact of Routine Evaluation of Gastric Residual Volumes on the Time to Achieve Full Enteral Feeding in Preterm Infants. Journal of Pediatrics, 189, 128134. https://doi.org/10.1016/j.jpeds.2017.05.054

Salas, A. A., Li, P., Parks, K., Lal, C. V, Martin, C. R., \& Carlo, W. A. (2020). Early Progressive Feeding in Extremely Preterm Infants: A Randomized Trial. The American Journal of Clinical Nutrition, 107(3), 365-370. https://doi.org/https://doi.org/10.1093/ajcn/nqy012

Sojasi, S. S., Gebreili, M., Assadollahi, M., Hosseini, M. B., \& Jafarabadi, M. A. (2018). Determination and Comparison of Stomach Residual Volume at Two Alternate Gavage Ways with Gravity and Injection Force in Premature Infants. Bali Medical Journal, 7(1), 170-176. https://doi.org/10.15562/bmj.v7i1.795

Song, D., Jegatheesan, P., Nafday, S., Ahmad, K. A., Nedrelow, J., Wearden, M., Nemerofsky, S., Pooley, S., Thompson, D., Vail, D., Cornejo, T., Cohen, Z., \& Govindaswami, B. (2019). Patterned Frequency-Modulated Oral Stimulation in Preterm Infants: A Multicenter Randomized Controlled Trial. Plos One, 14(2), 115. https://doi.org/10.1371/journal.pone.0212675

Tarigan, I. U., Afifah, T., \& Simbolon, D. (2017). Faktor-Faktor yang Berhubungan dengan Pelayanan Bayi di Indonesia: Pendekatan Analisis Multilevel Factors Related with Infant Health Services: Multilevel Analyses Approach. Jurnal Kesehatan Reproduksi, 8(1), 103-118. https://doi.org/10.22435/kespro.v8i1.6879.103-118

Teams, N. P. C. (2017). Neonatal Clinical Practice Guideline: Enteral Feeding of Preterm and Highrisk Neonates. Winnipeg Regional Health Authority

Una, T. U. M. N. and A. (2019). Procedure for Enteral Tube feeding in the Neonatal /SCBU environment

Wertheimer, F., Arcinue, R., \& Niklas, V. (2019). Necrotizing Enterocolitis: Enhancing Awareness for the General Practitioner. Pediatrics in Review, 40(10), 517-527. https://doi.org/https://doi.org/10.1542/pir.2017-0338 